\title{
Research on the Universality of College English Teaching Mode under the Background of College Entrance Examination Reform and Autonomous Learning Concept
}

\author{
Wenxiao Zhu \\ Henan University of Traditional Chinese Medicine, \\ Zhengzhou,Henan, 450008 China
}

\begin{abstract}
In this paper, we conduct research on the universality of college English teaching mode under the background of college entrance examination reform and the autonomous learning concept. Autonomous learning is corresponding with the traditional accepting study a kind of modern learning style, take the student as the main body of learning, through the analysis of students' independence, exploration, practice, questioning and creation method to achieve learning goals. Innovation ability is to use the knowledge and theory, the science, art, technology and the field of all kinds of practical activities to provide has economic value, social value and ecological value of new thoughts, new theory, new method and new inventions. Under this background, we combine the college entrance examination reform principles to propose the novel perspective on the universality of college English teaching mode that is novel and innovative.
\end{abstract}

Keywords-English Teaching, Entrance Examination, College, Reform, Autonomous Learning.

\section{Introduction}

College English classroom is the main place to university students' English learning, that pay attention to cultivation of students' language ability. English classroom teaching is the main object personality is distinct, independence is stronger and different ideas of college students, makes with other levels of English teaching in the class of the college English teaching class is a big difference. College English classroom teaching goal is diverse, and the college English classroom teaching is not only to make students master English language knowledge, cultivate the students' second language skills, but also let the students know how to explore independently, independent of the teaching content, exercise the student's psychological quality, to help students form the scientific mode of thinking and to promote the all-round development of the students [1-3].

The author thinks that, English teachers' spirit of innovation should be reflected in the courage to break the traditional teaching mode, dare to innovation, challenge. It is based on classroom teaching and to break through the bondage of class flexible selection of the teaching materials and the teaching means while abandon the old think of the idea of the English teaching and research are made useless, absorbing the latest research results at home and abroad to our advantage, and in practice and improve on the argument. Based on the literature review, we could summarize challenges for modern English education as the follows. (1) Single teaching methods. University education should be to cultivate the students thinking, the comprehensive quality of research, language expression and in general English language communication ability should be cultured. However, the teaching model of college English teaching in China is still in high school, the lack of new idea. It is still the first words, based on the analysis of the grammar, reading the text, 
sentence translation for the text content, word for word interpretation model. (2) Old English teaching content. Teaching material is constant for a long time as years of teaching English teacher for textbooks have become adept and know knowledge points, have certain advantages, but to a certain extent it reduce the teacher teaching mode innovation.

The goal of modern college English teaching is to cultivate higher level of the English compound professionals, higher professional quality.
Throughout the training process, with the beginning of the English language learning, including the language skills and language application, namely the total nuclear English and English for the special purposes, and the improvement of the professional quality through English application in the course. For the better understanding of our later discussion, in the figure one, we show the general flowchart and architecture of the Chinese education system.

\section{China's education structure}

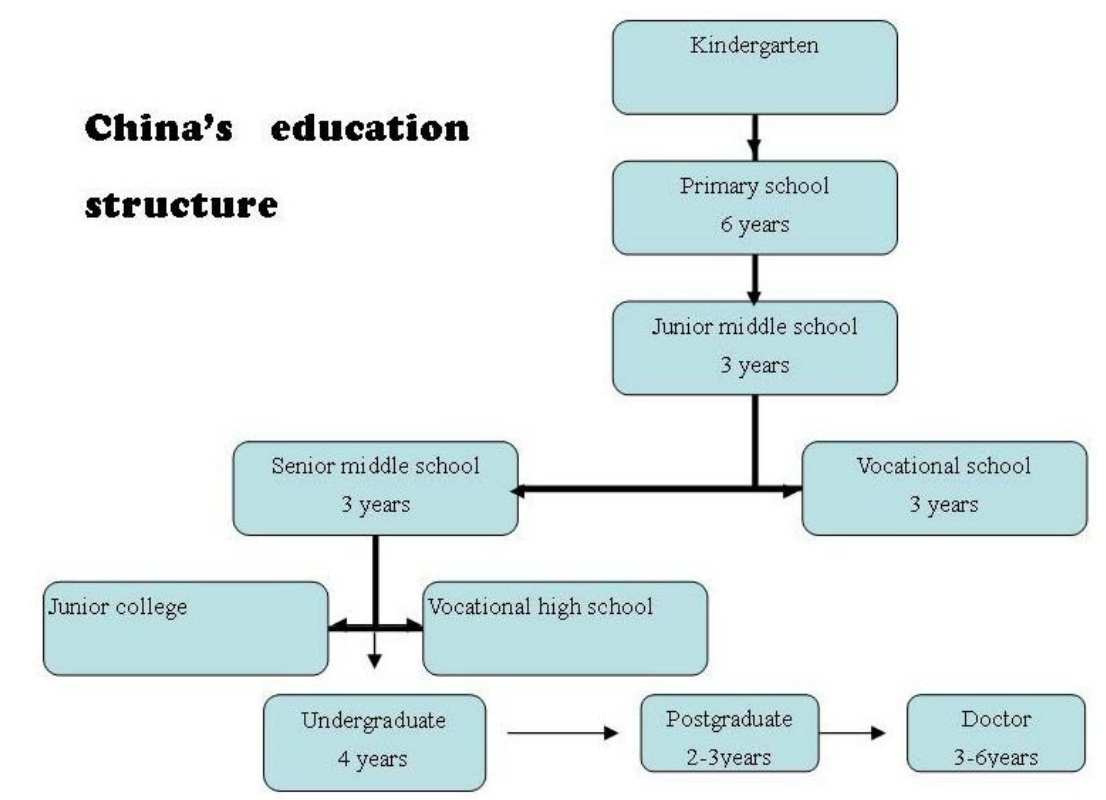

Figure 1. The General Flowchart and Architecture of the Chinese Education System

In this paper, we conduct research on the universality of college English teaching mode under the background of college entrance examination reform and the autonomous learning concept. In the later sub-sections, we will discuss the corresponding issues in detail.

\section{The Proposed Methodology}

The College Entrance Examination Reform. College entrance examination in the process of the development of our country gradually formed the two basic functions: one is choose for the various professional institutions of higher learning meets the needs of cultivating qualified freshmen as the other one is to guide the healthy progress of basic education toward the direction of development.

Throughout the modern world college freshmen enrollment system of major developed countries, in which colleges and universities are at the core responsibility main body status. The United States, for example, college freshman admissions independently completed entirely by general colleges and universities. These performances include: academic curiosity, shown in the learning initiative and subject preferences as well as in social practice and the interest shown in personalized extracurricular activity, development potential and leadership and so on. Importantly, different schools of different professionals are based on their training 
experience and professional requirement point of observation and evaluation, and give them different in their freshman admission criteria weight status [4-5].

The author thinks that the foreign language college entrance examination reform and its policies have the following several significant features. (1) The education administrative department of the socialization of specific test plan has not been formed. Therefore, foreign language academic circles, especially in the test and evaluation experts, should be with high sense of responsibility and urgency, relevant countermeasures study and put forward valuable Suggestions. (2) The decision, in the form of the central committee of the communist party of China big decision shows that the measure has the important political significance, accurate understanding of the decision of the political background and the education policy implication is crucial to any misunderstanding and distortion effect on the effective implementation of the decisions and the subsequent immeasurable negative effect. The author believes that the decision should be designed to reduce the burden, ease the students, parents, school and society all kinds of pressure because of the college entrance examination. (3) Department in charge of education, academia and foreign language teaching experts have a responsibility to help eliminate the doubts as soon as possible, to minimize the reform may bring negative effect maximize the profitability of the reform as the foreign language teaching and assessment way to return to the rational and scientific track. Foreign language college entrance examination reform, therefore, will be a great event in the history of China's foreign language education, to the basic education stage of the foreign language teaching, foreign language teaching at the university of incalculable impact, such as worthy of attention highly education and foreign language.

The Autonomous Learning Concept. At present, autonomous learning has become the focus of the education research topic at home and abroad. Autonomous learning is a learning attitude, is a kind of the independent learning ability. In the present teaching in the field of education, students in the process of autonomous learning affected by a lot of internal or external factors, lead to students during the process of autonomous learning faced many difficulties and the learning effect is not obvious. The influence factors of basic autonomous learning are various, mainly from the following two aspects to analyze factors affecting students' autonomous learning. (1) Teaching mode is in a certain teaching ideas or teaching under the guidance of the theory to build a relatively stable structure of the teaching activities and activity program. At present, many colleges and universities still adopt the large class teaching mode and it is bad for student autonomous learning. Good make class lively and the flexible teaching mode, students are more likely to study atmosphere, learn knowledge, inspire potential and help the students find their own way to learn more and methods, so as to improve efficiency and achieve the goal of learning. (2) Self-efficacy refers to people on their can successfully complete the achievements of a subjective judgment and speculation. People tend to choose their own feel able and have the confidence to complete the task, to avoid the feeling is not completed or no faith or up to the activities of the task. Self-efficacy is an important psychological factor that influences the students' learning ability and personality development, as an important influence on the students' autonomous learning, and affects the overall development of college students' self-consciousness and the learning potential of play and the formation of the personality [6]. 


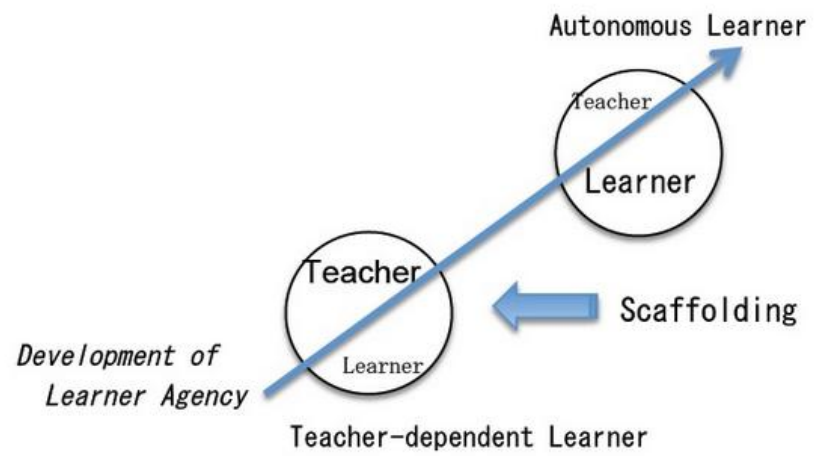

Figure 2. The Demonstration of the Autonomous Learning Concept

In the process of autonomous learning, the main body as autonomy is the function of the system cannot be ignored according to the theory of cognitive point of view: the autonomy of the functional system including driving system, power system and the control system. Drive system is refers to the various elements of the subjective consciousness of the organic structure of consciousness. These subjects include demand consciousness, value consciousness and self-consciousness and so on. Main aim in life, learning goals, achievement goal setting, the formation of the value goal and seek positive regard self-consciousness is the main body in the system to implement and complete drive system. Drive system, therefore, the fundamental role of the set is put forward and cognitive purpose to make subject's cognitive activity produces certain directivity and ability to other elements of the cognitive subject system organically, make the body consciously and actively participate in cognitive activities enthusiastically. Autonomous learning that learners can identify the teachers' teaching goal and they know what to learn, know how to determine their own learning goals, and be able to rebuild the teachers' teaching goal, in order to satisfy their own changing knowledge, they will be able to choose and use appropriate learning strategies, and to monitor strategy, make adjustments when necessary, to monitor the effect of learning that can be seen from the above definition, autonomous learning is not a kind of teaching method, but the learners grasp the ability of learning. This kind of ability and other aspects of personal ability can be trained to get learning and can improve through constant practice.

The Universality of College English. About the universal law of learning is not so mysterious, as some people think that looked to be in, but no find. In fact in life we are in the use of a model of the universal rules to guide their thinking and action, just because we didn't notice that. Linguists agree that in the different teaching activities, the teacher should play different roles, and as the change of the teaching activities and teaching objectives, teachers will play the role of the corresponding change.

Professional particularity in the language teacher, English teacher at the time of its role, we must firmly grasp the service based on the principles of each student, in the teaching activity to set up with the concept of the individual students as the main body, and each student to achieve full of the positive interaction. In other words, English teachers can't see the whole class as a target in general. Language teaching is very specific, and even specific to each word, each syllable and each vowel and consonant. This requires English teacher must adopt different strategies for different students. In the process of English teaching, the students from beginning to end will be directly involved in the teaching contents and teaching means of implementing the decision. Because students if stay out, teachers will not be able to accurately assess their own teaching design is in accordance with the needs of the students, whether very targeted. So here must dialectical view of the "leading" role of English teachers in the teaching, can't simply believe that advocates the dominant role of English teachers in the teaching is completely by the teacher in charge. But should be up to understand from the teaching purpose, that is, the role of teachers in line with the aims to make the development of the language skills and learning skills, and to make the students as the main body of the learners consciousness to strengthen, so 
that the students learning objective and learning needs to be able to clear principle.

The Future of English Education. For effective college English teaching classroom, teachers can be accurate to shed light on the teaching content and help the students better understand and grasp the teaching contents, this is also the important embodiment of the university teaching class effectively. Before college English teachers in the teaching activities, it is necessary to define important purpose of teaching activities, the strict grasp the arrangement to the student's problems in classroom teaching and learning task, let students understand the teaching content in teaching practice. Under this guide, we should follow the listed suggestions [7-8].

- Create a multi-dimensional interactive teaching mode. In creating a more interactive teaching mode, the maintenance to be able to fully understand modern English autonomous learning, multimedia classroom teaching with application ability of the three-dimensional integrated teaching basic knowledge of the importance. Multimedia classroom teaching fundamentally changed the blackboard writing teaching model, combining the theory of comprehensive English course teaching requirements and teaching method, using multimedia to cooperate design, so as to expand students' thinking ability, enhance the purpose of students' interest.

- Set up a cooperative learning group. Team belongs to one of the effective methods of English teaching activities, combined with the specific content of teaching teachers to choose the oral presentations, with group discussions, formal conversation, class debate and other forms of the teaching, so as to enhance the teaching effect.
- Through the teaching resources integration realize the interaction between people and the environment. Interactive teaching mode is based on harmony based on learning atmosphere of equality, democracy, so as to help students form mutual understanding, trust, communication and cooperation relationships.

Based on the facts of the foundation weak students, teachers design teaching task teaching goal setting should first tend to study language form, the second is the language communication, which requires the design of the task step by step, from easy to difficult, from language form task gradually transition to the communicative task that will help obtain better education performance.

\section{Conclusion}

In this paper, we conduct research on the universality of the college English teaching mode under the background of college entrance examination reform and the primary autonomous learning concept. Comprehensive English course, as a backbone lesson foundation stage of English major education in colleges and universities, with its involves material to a wide variety, the feature of comprehensive training students' language communication ability become the compulsory course for English majors in colleges and universities irreplaceable. This course teaching methods for students learning methods and learning habits of the influence of cannot be ignored. Therefore, this paper combined with the characteristics of this course and cultivate autonomous learning ability of various elements, analyzed the comprehensive English course in colleges and universities in the strategies and means of training students' autonomous learning ability. In the recent future, we will conduct more in-depth analysis and research to polish the proposed mode. 


\section{References}

[1] Jigang, Cai. "The Orientation of College English Teaching Revisited: EGP and ESP." Journal of Zhejiang University (Humanities and Social Sciences) 4 (2015): 010.

[2] Jigang, C. A. I. "The Impact of Subject-based English and Its Teaching Materials on ESP Teaching in China [J]." Foreign Languages and Their Teaching 2 (2013): 002.

[3] Li, Xin-Guo. "Computer-Web-Based Multimedia College English Teaching Assessment Model with Uncertain Linguistic Information." Advances in Information Sciences \& Service Sciences 4.13 (2012).

[4] Wang, Wei, and Jianhua Zhai. "Multi-disciplinary internet-based platform in optimizing college English teaching." International Conference on Information,
Business and Education Technology (ICIBIT 2013). Vol. 10371042. 2013.

[5] Xu, L. I. U. "Cultivation of the Inter-cultural Communication Abilities in Interpretation Class of University English Teaching." Journal of Shijiazhuang Tiedao University (Social Science) 1 (2013).

[6] Yue, Xia. "Business English Teaching Method Innovation of Viewing-Listening-Speaking Trinity." China Educational Technology \& Equipment 18 (2013): 035.

[7] Ke, Li. "On university English grouping teaching from the perspective of the task-based theory [J]." Journal of Jiamusi Education Institute 10 (2012): 231.

[8] Fangyan, Liu, and Guo Minghui. "Research and Exploration of Specialized English Teaching Reform of Wood Science and Engineering." Forest Engineering 5 (2013): 041. 